\title{
KETERHUBUNGAN ANTARA KEMAMPUAN, KEBAJIKAN (BENEVOLENCE), DAN INTEGRITAS PERUSAHAAN TERHADAP KEPERCAYAAN DAN PARTISIPASI PELANGGAN: STUDI EMPIRIS PADA TOKOPEDIA
}

\author{
Lidya Gunarso', Jeremy Andriano², Sabrina O. Sihombing ${ }^{3}$ \\ ${ }^{1}$ Jurusan Manajemen, Universitas Pelita Harapan Tangerang \\ Email: lidya.gunarso99@yahoo.com \\ ${ }^{2}$ Jurusan Manajemen, Universitas Pelita Harapan Tangerang \\ Email:andrianootedja@gmail.com \\ ${ }^{3}$ Jurusan Manajemen, Universitas Pelita Harapan Tangerang \\ Email: sabrina.sihombing@uph.edu
}

\begin{abstract}
ABSTRAK
Penelitian ini bertujuan untuk memprediksi keterhubungan antara kemampuan, kebajikan, dan integritas Tokopedia terhadap kepercayaan dan partisipasi pelanggan Tokopedia. Sebanyak 130 responden terlibat dalam penelitian ini. Kueioner dikembangkan berdasarkan indikator-indikator penelitian sebelumnya. Skala Likert 5 poin digunakan dalam kuesioner tersebut. Sebelum data dianalisis dengan menggunakan structural equation modeling, data terlebih dahulu diuji reliabilitas dan validitasnya. Hasil analisis menunjukkan bahwa terdapat 3 dari tujuh hipotesis yang tidak didukung dalam penelitian ini. Ketiga hipotesis tersebut berkaitan dengan kebajikan dan integritas tidak mempunyai keterhubungan yang positif dengan kepercayaan konsumen. Lebih lanjut, tidak keterhubungan positif antara kebajikan perusahaan dengan tingkat partisipasi konsumen. Pembahasan serta keterbatasan penelitian juga disampaikan.
\end{abstract}

Kata Kunci: Kemampuan, Kebajikan, Integritas, Kepercayaan, Partisipasi

ABSTRACT

This study aims to predict the relationship between the ability, benevolence, and integrity of Tokopedia to the trust and participation of Tokopedia customers. A total of 130 respondents were involved in this study. The questionnaire was developed based on the indicators of previous studies. A 5-point Likert scale was used in the questionnaire. Before the data are analyzed using structural equation modeling, the data are first tested for reliability and validity. The analysis shows that there are thress of the seven hypotheses that are not supported in this study. The three hypotheses related to benevolence and integrity do not have a positive relationship with consumer confidence. Furthermore, there is no positive relationship between the benevolence of the company and the level of consumer participation. Discussion and limitations of the study were also conveyed.

Keywords: Ability, Benevolence, Integrity, Trust, Participation

\section{PENDAHULUAN}

\section{Latar Belakang}

Perkembangan teknologi yang semakin canggih dan melahirkan beberapa penemuan-penemuan baru di sektor teknologi. Perkembangan teknologi ini kerap memiliki manfaat yang bermula dari hadirnya Internet. Teknologi internet yang memberi kemudahan mendukung setiap masyarakat dalam melakukan berbagai aktivitas yang diinginkan. Salah satu implikasi dapat terlihat dari perkembangan teknologi berasal dari internet ini yakni dengan perubahan bentuk transaksi jual beli. Bermula dari bentuk transaksi jual beli biasanya harus dilakukan secara tatap muka sekarang sudah dimudahkan karena perkembangan teknologi internet yang membuat inovasi baru dengan menggunakan sebuah aplikasi transaksi jual beli secara online. Pelanggan mulai beradaptasi dengan perkembangan bertransaksi secara jelas ini dan meninggalkan cara lama dalam bertransaksi. 
Seiring dengan berkembangnya transaksi secara online ini maka menimbulkan semakin bertambah jumlah aplikasi online shopping/ e-commerce (penjualan daring). Penjualan daring merupakan sebuah konsep dimana konsep ini menggambarkan suatu proses jual beli atau pertukaran produk, jasa, dan juga informasi melalui jaringan-jaringan internet (Sudjatmika, 2017). Di Indonesia memiliki cukup banyak situs e-commerce diantaranya Bukalapak, BliBli, Shopee, Tokopedia, Lazada, dan sebagainya.

Perkembangan teknologi juga mempengaruhi peningkatan jumlah transaksi online yang terjadi. Hal ini disebabkan oleh kemudahan para pengguna mendapatkan barang yang dibutuhkan. Seperti yang diberitakan oleh cnnindonesia (2019), 86\% pengguna internet di Indonesia melakukan pembelian daring dari perangkat apapun. Padahal, dari riset yang dilakukan menunjukan bahwa transaksi yang dilakukan secara daring cukup berbahaya (Wong, 2017). Di satu sisi, Indonesia berada di posisi teratas dalam 10 negara yang jumlah perkembangan $e$ commerce tercepat di dunia (Widowati, 2019). Dan juga hal ini sesuai dengan pernyataan kominfo bahwa pertumbuhan e-commerce dalam negeri mencapai hampir $80 \%$, lebih tepatnya sebesar $78 \%$. Hal ini tidak mengejutkan karena berdasarkan data yang diberitakan oleh Tempo transaksi online yang terjadi berjumlah sekitar Rp. 13 Trilliun (Wahyudi, 2019). Hal-hal diatas lah yang memberikan kesempatan bagi Tokopedia untuk berkembang menjadi salah satu $e$ commerce terbesar yang ada di Indonesia.

Tokopedia sendiri merupakan media daring buatan anak bangsa yang lahir pada tahun 2009 . Tokopedia ditemukan oleh William Tanuwijaya dan rekannya Leontinus Alpha Edison. Sejak 2009 Tokopedia terus berkembang sampai saat ini hingga bisa menjadi salah satu unicorn yang dimiliki oleh bangsa Indonesia.Tokopedia ini berhasil memimpin pasar e-commerce Indonesia dengan jumlah transaksi mencapai 16,5 juta produk setiap bulan, dengan nilai mencapai miliar hingga triliunan rupiah yang diperkirakan akan terus meningkat (CNN Indonesia, 2017). Hal ini dikarenakan jumlah pengguna aktif Tokopedia juga terus bertambah hingga diperkirakan saat mencapai umurnya yang ke-10 jumlah penggunanya sudah sekitar 90 juta pengguna aktif. Menurut tech in asia situs resmi maupun aplikasi tokopedia rata rata dikunjungi oleh 137 juta pengguna tiap bulannya yang merupakan jumlah tertinggi dibandingkan dengan e-commerce lain yang ada di Indonesia (Kharisma, 2019).

Tokopedia awalnya hanya merupakan sebuah platform online yang menjadi perantara yaitu antara pembeli dan penjual yang ingin bertransaksi. Perusahaan ini berbasis internet dengan konsep C to C (Customer to Customer) (Alwafi, 2017). Dengan ini Tokopedia menyediakan platform agar pembeli bisa merasa lebih aman bertransaksi dengan penjual agar tidak tertipu. Tokopedia berkembang menjadi e-commerce yang lengkap menyediakan kebutuhan semua penggunanya. Mulai dari bekerja sama dengan beberapa brand resmi untuk menjadi official store di Tokopedia hingga menyediakan layanan perantara pembayaran tagihan seperti tagihan listrik, telepon, internet, dan lain-lain. Hal ini memicu semakin banyak pengguna internet yang kemudian menjadi pengguna aktif di Tokopedia. Hal ini dikarenakan semua kebutuhan dan pembayaran yang penting bagi pengguna bisa didapatkan atau diselesaikan melalui Tokopedia. Faktor lainnya karena kemudahan pembayaran yang disediakan oleh Tokopedia, pengguna bisa melakukan pembayaran melalui berbagai macam cara. Contohnya adalah pembayaran melalui bank transfer, virtual account, kartu kredit, dan lain sebagainya. Dengan kemudahan pembayaran yang tersedia, para pengguna menjadi memiliki ikatan dengan Tokopedia.

Transaksi yang dilakukan di platform e-commerce dapat berbahaya. Rosidawati dan Santoso (2013) menunjukkan setidaknya ada 600 situs penipuan di bisnis daring yang ada di Indonesia. 
Akan tetapi, transaksi di e-commerce justru semakin bertambah dari hari ke hari. Berkaitan dengan hal tersebut, penelitian mengenai pembelian daring telah banyak dilakukan (misalnya, Setyoparwati, 2019; Svare dkk. 2019; Firmansyah dkk, 2019; Purwanto, 2017; Haekal dan Bambang, 2016; Ahmad dan Chowdury, 2011). Variabel yang digunakan untuk memprediksi niat beli daring sering difokuskan pada kepercayaan (misalnya, Setyoparwati, 2019; Sabtu, 2018; Ujia dan Munawaroh, 2016; Suyanto dan Sunyoto, 2012; Tung et al., 2001 ), keamanan (misalnya, Sudjatmiko, 2017; Alwafi \& Rizal, 2016; Suyanto \& Sunyoto, 2012), integritas (misalnya, Firmansyah dkk, 2019; Listyorini, 2015; Suyanto \& Sunyoto, 2012), dan sebagainya. Akan tetapi tidak banyak penelitian yang menekankan pada benevolence (kebajikan) perusahaan untuk memprediksi niat beli daring (misalnya, Wong, 2017). Padahal, kebajikan merupakan salah satu unsur utama dalam pembentukan kepercayaan konsumen terhadap perusahaan. Oleh karena itu, penelitian ini mereplikasi penelitian yang dilakukan oleh Wong (2017) untuk memprediksi niat beli daring. Dalam penelitian tersebut, kebajikan merupakan salah satu prediktor dari niat beli daring.

Tujuan dari penelitian ini adalah untuk memprediksi keterhubungan antara kemampuan, kebajikan, dan integritas Tokopedia terhadap kepercayaan dan partisipasi pelanggan Tokopedia. Secara spesifik, hasil penelitian ini akan menunjukkan apakah kemampuan, kebajikan, dan integritas memiliki atau tidak memiliki keterhubungan dengan kepercayaan dan partisipasi pelanggan. Hasil penelitian ini, baik yang signifikan atau tidak signifikan, akan memberikan kontribusi bagi teori dan praktis. Bagi teori, replikasi terkait dengan penelitian dasar dan hal utama yang diperlukan untuk kemajuan pengetahuan dalam disiplin apa pun (Star, 2018; Easley dkk, 2000; Hubbard dkk, 1998). Epstein (1980, dikutip oleh Easley dkk, 2000) juga menunjukkan bahwa replikasi adalah persyaratan mendasar dalam sains. Bagi praktisi, hasil penelitian ini dapat memperlihatkan mengetahui faktor-faktor yang terkait dengan partisipasi pelangggan dalam membeli secara daring.

\section{Tinjauan Pustaka}

Partisipasi Pelanggan. Menurut Zhang (2018) partisipasi pelanggan mengarah pada seberapa jauh pelanggan terlibat dalam produksi layanan dan penyampaian dengan menyumbangkan upaya, pengetahuan, informasi, dan sumber daya lainnya, dan kontribusi pelanggan dianggap multidimensi. Sedangkan menurut Danarahmanto dkk (2019) partisipasi pelanggan sangat penting bagi perusahaan dalam mencapai keunggulan kompetitif yang berkelanjutan. Di sisi lain, partisipasi pelanggan juga dapat memperlambat kinerja perusahaan. Partisipasi pelanggan dalam proses pengembangan suatu produk dapat menghambat kinerja sedangkan jika partisipasi pelanggan dipertimbangkan dalam pengembangan ide maka dapat meningkatkan kualitas produk dan kinerja perusahaan (Danarahmanto dkk, 2019).

\section{Kemampuan}

Kemampuan merupakan keahlian umum yang dimiliki setiap individu (Surya dkk, 2014). Kemampuan seseorang akan menentukan juga perilaku seseorang dan hasil dari perilakunya tersebut. Kemampuan juga merupakan bakat yang ada pada seseorang dari lahir untuk melakukan suatu kegiatan baik secara fisik maupun mental yang didapat dari proses pembelajaran atau dari pengalaman sendiri. Kemampuan adalah kapasitas atau seberapa besar seseorang dapat melakukan suatu tugas. Setiap mausia pada dasarnya memiliki dua kemampuan dasar yaitu yang pertama kemampuan untuk melakukan aktivitas yang menggunakan kekuatan mental, contohnya seperti berpikir atau menyelesaikan masalah, kemampuan ini disebut sebagai kemampuan intelektual. Yang kedua adalah kemampuan yang muncul saat kita harus 
menggunakan keterampilan atau kekuatan untuk menyelesaikan masalah, kemampuan ini dinamakan kemampuan fisik (Wibowo dkk, 2017).

\section{Kebajikan (Benevolence)}

Kebaikan hati manusia sudah banyak dilakukan penelitiannya, dan telah ditemukan bahwa nilainilai kebaikan adalah suatu tindakan bermoral (Anastassia dkk, 2015). Mereka yang baik hati akan menggunakan semua kemampuan dan keterampilan mereka untuk membantu orang lain sebaik mungkin. Kebajikan bisa berupa kecenderungan untuk berbuat baik dan tindakan kebaikan, di mana wali amanat memiliki perasaan niat baik terhadap mitra yang berinteraksi tidak termasuk niat apa pun dari melukai dia diberi kesempatan untuk melakukannya. Kebajikan dalam dunia bisnis adalah niat penjual untuk memberi kepuasan tersendiri pada konsumen yang membuat keadaan menguntungkan untuk kedua belah pihak (Sabtu, 2018)

\section{Integritas}

Menurut Huberts (2018) integritas dalam bahasa Latin yaitu utuh dan harmonis. Integritas dapat diartikan sebagai keutuhan atau kelengkapan dan sebagai konsistensi dan koherensi prinsip dan nilai. Pandangan lain melihat integritas sebagai keutuhan atau tanggung jawab profesional (termasuk pandangan dengan fokus pada pertimbangan lingkungan). Integritas berarti bahwa seorang yang profesional menjalankan tugasnya secara memadai, hati-hati dan secara bertanggung jawab, dengan mempertimbangkan semua kepentingan yang relevan (Huberts, 2018). Jadi integritas merupakan sesuatu yang utuh secara keseluruhan, hal yang tidak terbagi, dan bulat. Meskipun integritas terdiri dari banyak elemen tetapi integritas itu selalu utuh, hal ini merupakan hasil dari hubungan timbal balik elemen-elemennya.

\section{Kepercayaan}

Ini melibatkan kepercayaan ketika satu pertemuan, misalnya organisasi dan klien memiliki kepastian satu sama lain untuk memiliki opsi untuk membuat koneksi yang umumnya berharga. Kepercayaan ini merupakan komponen penting karena merupakan premis dari koneksi yang dapat disetujui di masa depan, dan ketika kepercayaan ditanamkan antara satu pertemuan dengan yang lainnya, organisasi dan klien dapat memperoleh setiap keinginan mereka. Kepercayaan juga bisa diuraikan dengan kepastian dari satu pertemuan dengan pertemuan lainnya dalam menjaga hubungan. Kepercayaan ditandai sebagai kesiapan untuk bergantung pada kapasitas, kehormatan, dan inspirasi dari berbagai pertemuan untuk bertindak untuk memenuhi kebutuhan dan minat seseorang seperti yang biasa dan secara tegas diselesaikan (Utami, 2013). Kepercayaan pembelanja dipartisi menjadi 2 ukuran, untuk keyakinan-keyakinan spesifik dan harapan kepercayaan. Keyakinan kepercayaan adalah seberapa seseorang dapat menerima dan merasa yakin dengan orang lain dalam keadaan tertentu. Ini didukung oleh penilaian yang dikomunikasikan (Utami, 2013), bahwa keyakinan kepercayaan dapat dibingkai melalui tiga pengukuran, untuk spesifik: kapasitas, kebajikan, kejujuran.

\section{Partisipasi}

Menurut Laksmidewi (2014) partisipasi pelanggan merupakan suatu hal yang mempengaruhi kualitas dari hasil produksi sehingga kepuasan pelanggan dapat tercapai. Partisipasi pelanggan juga dapat didefinisikan sebagai tindakan dan kegiatan yang bertujuan untuk memengaruhi input pelanggan ke dalam produksi dan pengiriman layanan untuk meningkatkan positif hasil dan mengurangi konsekuensi negatif bagi penyedia layanan dan pelanggan (Mustak dkk.,2016). Laksmidewi mengatakan bahwa jika harapan dibawah jasa maka yang terjadi adalah rendahnya kepuasan pelanggan dibandingkan jika pelanggan ikut berpartisipasi karena ia akan merasakan kesuksesan sebagai hasil dari kinerjanya juga. Sebaliknya jika jasa dibawah harapan maka 
partisipasi pelanggan dapat menjadi strategi untuk mengurangi kesalahan yang dituduhkan oleh pelanggan ke perusahaan. Maka dari itu perusahaan harus dinilai membutuhkan partisipasi pelanggan dan harus mengevaluasi setiap pendapat pelanggan secara berhati-hati.

\section{Pengembangan Hipotesis}

\section{Keterhubungan antara kemampuan terhadap kepercayaan}

Kepercayaan adalah sebuah akibat dari penilaian pengguna layanan belanja online yang memiliki sistem yang benar dan dapat diandalkan (Selviana, 2019). Pelanggan membutuhkan kinerja/kemampuan yang baik dari tokopedia untuk bisa membangun kepercayaan antara pengguna dan perusahaan. Kemampuan yang baik itu bisa diberikan perusahaan melalui fasilitas dan kemudahan bagi pengguna yang bisa membuat pengguna terikat. Keterhubungan antara kemampuan dan kepercayaan sebagaimana dibuktikan dalam penelitian sebelumnya (Savre dkk, 2019; Choiriyah, 2014; Firdayanti, 2012, Selviana, 2019). Maka hipotesis penelitian dapat disampaikan sebagai berikut:

$\mathrm{H}_{1}$ : Ada keterhubungan positif antara kemampuan perusahaan dan kepercayaan konsumen.

\section{Keterhubungan antara kebajikan terhadap kepercayaan}

Tokopedia harus menunjukan niat baiknya terhadap pengguna dengan memberikan pengguna rasa aman dan tidak adanya niat untuk merugikan pengguna yang memakai fasilitas yang diberikan Tokopedia. Kebaikan hati adalah niat penjual dalam memberikan kepuasan yang saling menguntungkan antara kedua belah pihak. Dengan merasa jika Tokopedia berniat baik terhadap pengguna maka tingkat kepercayaan pengguna terhadap Tokopedia juga meningkat. Hal ini akan mendukung pernyataan Gausdal dkk (2019) yang menyatakan, "Organisasi yang baik hati adalah organisasi yang tidak hanya memikirkan kepentingannya sendiri tetapi juga mampu menyelaraskan minat ini dengan niat untuk berbuat baik dengan organisasi lain." Keterhubungan positif antara kebaikan hati dan kepercayaan ditemukan signifikan dalam penelitian sebelumnya (Savre, 2019; Sasongko dan Wahyudi, 2019; Setyoparwati, 2019). Dengan demikian, hipotesis yang dapat dituliskan adalah sebagai berikut:

$\mathrm{H}_{2}$ : Ada keterhubungan positif antara kebajikan perusahaan dengan kepercayaan konsumen.

\section{Keterhubungan antara integritas terhadap kepercayaan}

Di era di mana reputasi sangat penting untuk kesuksesan, integritas perusahaan adalah pertimbangan penting bagi perusahaan mana pun. Apapun yang perusahaan lakukan, jika perusahaan tidak menunjukkan integritas maka konsumen menjadi tidak percaya. Kepercayaan konsumen merupakan pondasi awal sebelum melakukan proses pembelian (Ujia dan Munarwoh, 2018). Keterhubungan positif antara integritas dan kepercayaan ditemukan signifikan dalam penelitian sebelumnya (Rofiq dan Mula, 2010; Firmansyah dkk, 2019; Dirgahayu dkk, 2010; Agustina, 2011; Ujia dan Munarwoh, 2018). Hipotesis penelitian dapat disampaikan sebagai berikut:

$\mathrm{H}_{3}$ : Ada keterhubungan positif antara integritas perusahaan dengan kepercayaan konsumen.

\section{Keterhubungan kepercayaan terhadap partisipasi}

Kepercayaan adalah dasar dari sebuah bisnis. Suatu transaksi bisnis antara dua pihak atau lebih akan terlaksana apabila kedua belah pihak saling mempercayai. Kepercayaan (trust) ini tidak begitu saja dapat diakui oleh pihak lain/mitra bisnis, melainkan harus dibangun mulai dari awal dan dapat dibuktikan (Wong, 2017). Partisipasi ditentukan oleh kepercayaan terhadap rekanan, media, atau lainnya yang terlibat dalam suatu kegiatan sehingga kepercayaan terhadap vendor akan mempengaruhi tingkat partisipasi pengguna (Ridwan, 2019). Keterhubungan antara kepercayaan dan partisipasi sebagaimana dibuktikan dalam penelitian sebelumnya dinyatakan 
dalam hipotesis berikut (Ismunandar dan Mulyadin, 2018; Koirala dkk, 2018; Wahyudi dkk, 2013; Windarsyah dan Dirgahayu, 2010; Ridwan, 2019):

$\mathrm{H}_{4}$ : Ada keterhubungan positif antara kepercayaan konsumen dengan tingkat partisipasi konsumen.

\section{Keterhubungan kemampuan terhadap partisipasi}

Kemampuan lebih dari sekedar pelayanan terhadap individu, tetapi lebih pada semua aspek tentang bagaimana melakukan bisnis (Haekal dan Widjajanta, 2016). Secara spesifik dapat dikatakan bahwa jika perusahaan tidak bisa memberikan konsumen apa yang diharapkan maka konsumen akan kehilangan kepercayaan (Ahmad dan Chowdury, 2011) karena jika Tokopedia tidak memiliki kemampuan untuk memberikan ekspektasi yang konsumen harapkan maka tingkat partisipasi akan menurun. Keterhubungan positif antara kemampuan dan partisipasi sebagaimana dibuktikan dalam penelitian sebelumnya (Ismunandar dan Mulyadin, 2018; Ahmad dan Chowdury, 2011; Haekal dan Widjajanta, 2016; Ribadu dan Rahman, 2019; Purwanto, 2017). Maka hipotesis penelitian yang dapat disampaikan adalah:

$\mathrm{H}_{5}$ : Ada keterhubungan positif antara kemampuan perusahaan dengan tingkat partisipasi konsumen.

\section{Keterhubungan kebajikan terhadap partisipasi}

Seperti yang tertulis diatas, kebaikan hati merupakan kemauan penjual dalam memberikan kepuasan yang saling menguntungkan antara kedua belah pihak. Keuntungan yang diperoleh penjual dapat dimaksimalkan, tetapi kepuasan konsumen juga tinggi (Setyoparwati, 2019). Jika pengguna tidak menemukan hal yang baik dari penggunaan tokopedia, secara khusus, jika perusahaan tidak memiliki ketulusan dalam melakukan kebaikan kepada mereka, maka tidak akan ada kepercayaan konsumen yang akan berpengaruh terhadap partisipasi konsumen (Ahmad dan Chowdury, 011). Keterhubungan positif antara kebajikan dan partisipasi sebagaimana dibuktikan dalam penelitian sebelumnya dinyatakan dalam hipotesis berikut (Setyoparwati,2019; Ismunandar dan Mulyadin, 2018; Haekal dan Widjajanata, 2016; Ahmad dan Chowdury, 2011; Ribadu dan Rahman, 2019):

$\mathrm{H}_{6}$ : Ada keterhubungan positif antara kebaikan hati perusahaan dengan tingkat partisipasi konsumen.

\section{Keterhubungan integritas terhadap partisipasi}

Seperti yang dijelaskan diatas, integritas adalah salah satu faktor penting yang bisa menentukan keberhasilan dalam proses transaksi. Integritas memiliki hubungan langsung dengan bagaimana perilaku atau kebiasaan penjual dalam menjalankan bisnisnya. (Wong, 2017) Seiring dengan tokopedia menunjukan integritasnya dengan memegang janji promosinya maka semakin banyak juga orang yang tadinya bukan pengguna menjadi tertarik untuk menggunakan tokopedia yang terkenal memegang janji promosinya kepada pengguna. Hal ini sesuai dengan pernyataan penelitian sebelumnya yaitu "dengan demikian, integritas vendor dan kepercayaan konsumen adalah variabel yang sangat penting dalam pengaruh partisipasi konsumen e-commerce di Indonesia." (Purwanto, 2017) Pengaruh positif antara integritas dan partisipasi sebagaimana dibuktikan dalam penelitian sebelumnya dinyatakan dalam hipotesis berikut (Ismunandar dan Mulyadin, 2018; Setyoparwati, 2019; Purwanto, 2017; Ahmad dan Chowdury, 2011; Eniyati dkk, 2018)

$\mathrm{H}_{7}$ : Ada keterhubungan positif antara integritas perusahaan dengan tingkat partisipasi konsumen. 


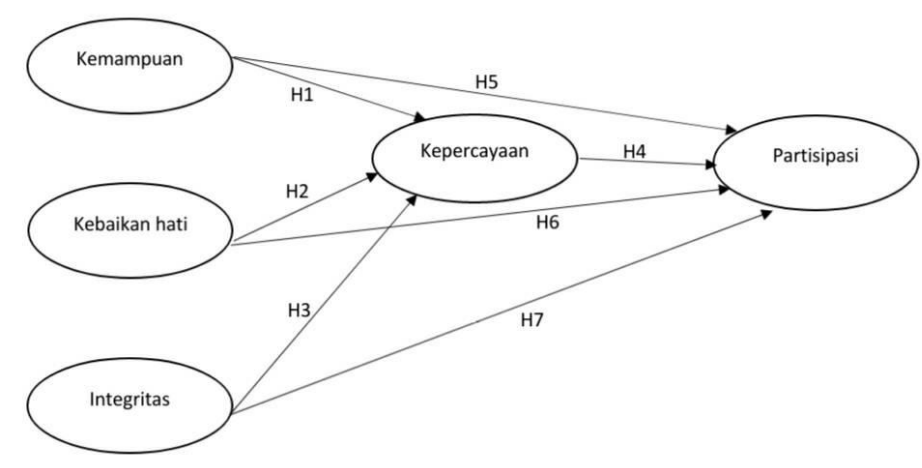

Gambar 1. Model Penelitian

Sumber : Wong (2017)

\section{METODE PENELITIAN}

Penelitian ini mengadopsi penelitian kuantitatif yang menggunakan metode purposive sampling. Penelitian ini menggunakan metode pengambilan sampel non-probabilitas untuk pengumpulan data karena lebih praktis (Sekaran dan Bougie, 2016). Untuk mengumpulkan data dari responden, purposive sampling dipilih berdasarkan kriteria sebagai berikut: ini: (1) Pengguna aktif internet maupun media sosial, (2) Berusia minimal 17 tahun, (3) Memiliki akun tokopedia, dan (4) Pernah melakukan transaksi di/melalui tokopedia.

Ukuran sampel yang lebih besar dari 30 dan kurang dari 500 sesuai untuk sebagian besar penelitian (Roscoe, 1975, dikutip oleh Sekaran dan Bougie, 2106). Oleh karena itu, penelitian ini menetapkan jumlah sampel sebesar 150. Akan tetapi, sekitar 130 kuesioner yang dapat digunakan diterima. Instrument untuk penelitian ini menggunakan kuesioner dengan pertanyaan tertutup terstruktur yang didistribusikan langsung kepada responden menggunakan kuesioner berbasis web yang dirancang menggunakan Formulir Google. Semua indikator penelitian didasarkan pada penelitian sebelumnya (Gefen dan Straub, 2004; Kim dkk, 2003; Tung dkk, 2001). Kuesioner menggunakan skala lima poin tipe Likert. Sebelum pengujian hipotesis, uji reliabilitas (Corrected-Item-To-Total Correlation, Cronbach Alpha, Composite Reliability) dan validitas dilakukan (AVE, Outer Loading). Uji reliabilitas digunakan untuk menentukan stabilitas dan konsistensi dengan instrumen penelitian yang mengukur konstruk (Sekaran dan Bougie, 2016). Dengan kata lain, keandalan berkaitan dengan stabilitas dan konsistensi dalam pengukuran. Masih dalam Sekaran dan Bougie (2016), uji validitas untuk memastikan bahwa pengukuran yang digunakan dalam penelitian ini adalah mengukur yang seharusnya diukur. Sesudah uji reliabilitas dan validitas dilakukan, maka data dianalisis dengan menerapkan structural equation modeling.

\section{HASIL DAN PEMBAHASAN}

Hasil analisis memperlihatkan bahwa Corrected-Item-To-Total Correlation, Cronbach Alpha, Composite Reliability menunjukkan keandalan untuk tiap indikator dan variabel penelitian. Hasil juga menunjukkan tercapainya validitas untuk tiap variabel penelitian (Tabel 1).

Tabel 1. Hasil uji Reliabilitas dan Validitas

Sumber: Analisis data (2020)

\begin{tabular}{|c|c|c|c|c|c|}
\hline \multirow[b]{2}{*}{ Variabel dan Indikator } & \multicolumn{3}{|c|}{ Reliabilitas } & \multicolumn{2}{|c|}{ Validitas } \\
\hline & $\begin{array}{l}\text { Corrected } \\
\text { Item Total } \\
\text { Correlation }\end{array}$ & $\begin{array}{c}\text { Cronbach's } \\
\text { Alpha }\end{array}$ & $\begin{array}{l}\text { Composite } \\
\text { Reliability }\end{array}$ & $A V E$ & $\begin{array}{c}\text { Outer } \\
\text { Loading } \\
(>0.7 t)\end{array}$ \\
\hline
\end{tabular}




\begin{tabular}{|c|c|c|c|c|c|}
\hline \multicolumn{6}{|l|}{ Kemampuan } \\
\hline 1. Tokopedia adalah perusahaan yang kompeten & 0.571 & 0.782 & 0.873 & 0.696 & 0.807 \\
\hline $\begin{array}{l}\text { customer dengan baik } \\
\text { Sava memiliki nonoalaman vano haru }\end{array}$ & 0.657 & & & & 0.85 \\
\hline $\begin{array}{l}\text { 3. Saya memiliki pengalaman yang baru } \\
\text { berbelanja online }\end{array}$ & 0.663 & & & & 0.845 \\
\hline
\end{tabular}

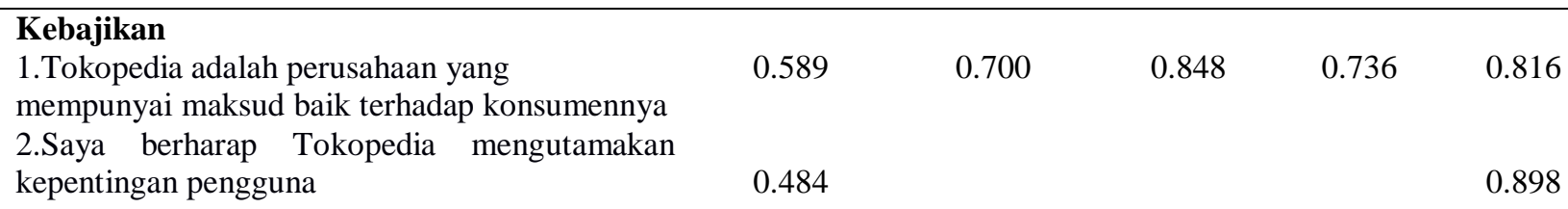

\section{Integritas}

1.Tokopedia menjamin keamanan data pelanggan

2.Tokopedia memegang janji promosinya

0.593

0.806

0.887

0.725

0.811

3.Tokopedia tidak memberi sembarang janji

\begin{tabular}{|c|c|c|c|c|c|}
\hline $\begin{array}{l}\text { Kepercayaan } \\
\text { 1.Saya mempercayai Tokopedia sebagai media } \\
\text { berbelanja saya }\end{array}$ & 0.711 & 0.877 & 0.904 & 0.759 & 0.877 \\
\hline \multirow{2}{*}{$\begin{array}{l}\text { 2.Saya nyaman berbelanja di Tokopedia } \\
\text { 3.Saya puas berbelanja di Tokopedia }\end{array}$} & 0.800 & & & & 0.869 \\
\hline & 0.785 & & & & 0.868 \\
\hline \multicolumn{6}{|l|}{ Partisipasi } \\
\hline $\begin{array}{l}\text { 1.Saya ingin meningkatkan frekuensi belanja di } \\
\text { Tokopedia }\end{array}$ & 0.694 & 0.841 & 0.926 & 0.806 & 0.872 \\
\hline $\begin{array}{l}\text { 2.Saya akan ikut merekomendasikan Tokopedia } \\
\text { kepada teman saya }\end{array}$ & 0.714 & & & & 0.915 \\
\hline 3.Saya akan terus berbelanja di Tokopedia & 0.709 & & & & 0.907 \\
\hline
\end{tabular}

Tabel 2 memperlihatkan hasil analisis dengan menggunakan structural equation modeling. Tabel ini menyajikan hasil analisis yang berkaitan dengan $T$-statistics dan $P$-value. Estimasi koefisien struktural terstandarisasi untuk semua variabel harus di atas 0,5 dan T-statistics di atas 1,96, yaitu ambang batas pada tingkat signifikan 0,05. Akan tetapi, hasil menunjukkan bahwa ada tiga hipotesis yang tidak didukung ( -statistics $<1.96$ ).

Tabel 2. Hasil Pengujian Hipotesis

Sumber : Analisis data (2020)

\begin{tabular}{|c|c|c|c|c|c|}
\hline & Hipotesis & $\begin{array}{l}\text { Original } \\
\text { Sample }\end{array}$ & $\begin{array}{l}\text { T- } \\
\text { statistics }\end{array}$ & $\begin{array}{c}\text { P- } \\
\text { value }\end{array}$ & Kesimpulan \\
\hline & $\begin{array}{l}\text { Ada keterhubungan positif antara kemampuan } \\
\text { perusahaan dan kepercayaan konsumen. }\end{array}$ & 0.416 & 3.477 & 0.001 & Didukung \\
\hline H2: & $\begin{array}{l}\text { Ada keterhubungan positif antara kebajikan } \\
\text { perusahaan dengan kepercayaan konsumen. }\end{array}$ & 0.14 & 1.436 & 0.152 & $\begin{array}{l}\text { Tidak } \\
\text { didukung }\end{array}$ \\
\hline H3: & $\begin{array}{l}\text { Ada keterhubungan positif antara integritas } \\
\text { perusahaan dengan kepercayaan konsumen. }\end{array}$ & 0.202 & 1.822 & 0.069 & $\begin{array}{l}\text { Tidak } \\
\text { didukung }\end{array}$ \\
\hline
\end{tabular}


H4: Ada keterhubungan positif antara kepercayaan konsumen dengan tingkat partisipasi konsumen.

H5: Ada keterhubungan positif antara kemampuan perusahaan dengan tingkat partisipasi konsumen. $\begin{array}{llll}0.486 & 5.985 & 0.001 \quad \text { Didukung }\end{array}$

$\begin{array}{llll}0.198 & 1.969 & 0.05 & \text { Didukung }\end{array}$

\begin{tabular}{|c|c|c|c|c|c|}
\hline H6: & $\begin{array}{l}\text { Ada keterhubungan positif antara kebajikan } \\
\text { perusahaan dengan tingkat partisipasi konsumen. }\end{array}$ & 0.046 & 0.506 & 0.613 & $\begin{array}{c}\text { Tidak } \\
\text { didukung }\end{array}$ \\
\hline H7: & $\begin{array}{l}\text { Ada keterhubungan positif antara integritas } \\
\text { perusahaan dengan tingkat partisipasi konsumen. }\end{array}$ & 0.173 & 2.092 & 0.037 & Didukung \\
\hline
\end{tabular}

\section{Pembahasan}

Penelitian ini bertujuan untuk menguji model dengan menganalisa apakah ada pengaruh kemampuan, kebaikan hati, dan integritas terhadap kepercayaan implikasinya terhadap partisipasi pelanggan. Dari hasil penelitian menunjukan bahwa dari 7 hipotesis yang dilakukan, ada tiga hipotesis yang tidak didukung. Ketiga hipotesis tersebut adalah berkaitan dengan hubungan antara kebajikan dan kepercayaan konsumen, integritas perusahaan dan kepercayaan konsumen, dan kebajikan perusahaan dan partisipasi konsumen.

Hasil menunjukkan bahwa hipotesis yang berkaitan dengan keterhubungan positif antara kebajikan perusahaan dengan kepercayaan konsumen tidak didukung. Menurut Rofiq dan Mula (2010) kebajikan merupakan bagian atau dimensi dalam kepercayaan. Dalam konteks ecommerce, kepercayaan pelanggan bisa didapat jika toko/merk di dalamnya memiliki rating yang baik dan rating yang baik itu mencerminkan kebaikan/niat baik dari vendor atau penjual (Joo, 2015). Berkaitan dengan hal ini, Tokopedia belum memberikan kapasitas sepenuhnya dalam menyeleksi toko/merk yang masuk ke dalam Tokopedia sehingga hanya terdapat sejumlah toko/merk saja dalam Tokopedia yang memiliki rating baik. Kurangnya jumlah toko/merek yang memiliki rating baik inilah yang menyebabkan pelanggan merasa kurang yakin dalam hal partisipasi pembelian di Tokopedia. Hasil hipotesis yang ditolak ini, ditolak juga pada penelitian sebelumnya dimana dinyatakan bahwa kebaikan hati tidak mempengaruhi kepercayaan dan partisipasi oleh Mulyani dkk (2016), Rofiq dan Mula (2010), dan Wong (2017).

Hipotesis yang menunjukkan bahwa ada keterhubungan positif antara integritas perusahaan dengan kepercayaan konsumen tidak didukung. Hal ini dapat dijelaskan kenapa integritas Tokopedia tidak mempengaruhi kepercayaan pelanggan, hal ini dikarenakan produk yang akan dibeli semuanya sudah jelas spesifikasinya dari masing-masing toko/merk. Pelanggan juga dapat menghubungi masing-masing penjual melalui fasilitas chatting di aplikasi Tokopedia. Maka dari inilah yang harus dikhawatirkan bukanlah integritas Tokopedia melainkan integritas masinmasing toko/merk didalamnya. Khususnya indikator-indikator yang peneliti gunakan pada variabel integritas semuanya mengacu pada integritas Tokopedia bukan pada integritas merk tertentu di dalamnya, maka dari itulah hasil yang didapat adalah integritas Tokopedia tidak berpengaruh pada kepercayaan pelanggan. Hasil penelitian ini juga mendukung penelitian sebelumnya yang menunjukkan tidak ada keterhubungan yang signifikan antara integritas perusahaan dengan kepercayaan konsumen (misalnya: Suyanto, 2012).

Hipotesis menyatakan bahwa ada keterhubungan positif antara kebajikan perusahaan dengan tingkat partisipasi konsumen juga tidak didukung. Hal ini dapat menunjukkan bahwa Tokopedia belum dirasakan menunjukkan kepedulian terhadap konsumen terutama pada saat konsumen 
mengalami masalah dengan pihak toko yang bergabung dengan Tokopedia. Hipotesis ketujuh menunjukkan bahwa ada keterhubungan positif antara integritas perusahaan dengan tingkat partisipasi konsumen. Hasil penelitian mendukung hipotesis penelitian ini. Hasil penelitian ini juga mendukung hasil penelitian-penelitian sebelumnya (Mulyadin dan Ismunandar, 2018; Setyoparwati, 2019; Purwanto, 2017; Ahmad dan Chowdury, 2011; Eniyati dkk, 2018).

\section{KESIMPULAN DAN SARAN}

Penelitian ini bertujuan untuk memprediksi keterhubungan antara kemampuan, kebajikan, dan integritas Tokopedia terhadap kepercayaan dan partisipasi pelanggan. Hasil analisis menunjukkan bawah terdapat tiga dari tujuh hipotesis yang tidak didukung. Ketiga hipotesis tersebut adalah (1) Tidak ada keterhubungan positif antara kebajikan perusahaan dengan kepercayaan konsumen, (2) Tidak ada keterhubungan positif antara integritas dan kepercayaan konsumen, serta (3) Tidak ada keterhubungan positif antara kebajikan dan tingkat partisipasi konsumen. Penelitian ini tidak lepas dari keterbatasan penelitian. Keterbatasan utama adalah penggunaan disain sampling non probabilitas memberikan konsekuensi bahwa hasil penelitian ini tidak dapat digeralisasi. Kemudian, keseluruhan sampel pada penelitian ini adalah mahasiswa. Padahal, pengguna Tokopedia berasal dari beragam umur dan beragam profesi. Kemudian, penelitian ini adalah penelitian cross-sectional yang hanya menggambarkan fenomena dan situasi pada satu waktu saja.

\section{Implikasi Manajerial}

Hasil penelitian ini menunjukkan bahwa kemampuan perusahaan serta integritas perusahaan merupakan faktor utama yang berkaitan erat denga kepercayaan dan partisipasi konsumen dalam konteks pembelian daring. Oleh karena itu,perusahaan perlu terus menjaga serta meningkatkan kemampuannya dalam melayani konsumen dengan tetap menitik-beratkan pada integritas perusahaan. Dengan demikian, konsumen kemudian akan terus percaya dan berpartsipasi pada pembelian daring.

\section{REFERENSI}

Anastassia, D., Milla, M. \& Hafiz, S (2015). Nilai-Nilai Kebajikan: Kebaikan Hati, Loyalitas, dan Kesalehan dalam Konteks Budaya Melayu. Jurnal Psikologi Ulayat, 2(1), 335-347.

Agustina,D. (2011). Hubungan Dimensi Kepercayaan (Trust) Dan Dimensi Kualitas (Quality)

Dengan Partisipasi Pelanggan E-Commerce: Studi Pada Pelanggan E-Commerce di Yogyakarta. Jurnal Ilmiah Gema, 1(2),. 95-108.

Ahmad, N. \& Chowdury, M. (2011). Factors Affecting Consumer Participation in Online Shopping in Malaysia: The Case of University Student. European Journal of Business and Economics. 5 , https://www.researchgate.net/publication/269433618_Factors_Affecting_Consumer_Partic ipation_In_Online_Shopping_In_Malaysia_The_Case_Of_University_Students

Alwafi, F. \& Magnadi, R. (2016). Pengaruh Persepsi Keamanan, Kemudahan Bertransaksi, Kepercayaan terhadap Toko dan Pengalaman Berbelanja terhadap Minat Beli Secara Online pada Situs Jual Beli Tokopedia.com. Diponegoro Journal of Management, 5(2), 115.

CNN Indonesia (2019). Netizen Indonesia Paling Gemar Belanja Online. https://www.cnnindonesia.com/teknologi/20190201173813-185-365769/netizen-indonesiapaling-gemar-belanja-online

Danarahmanto, A. P., Primiana, I. \& Kaltum, U. (2019). The Sustainable Perfomance of The Digital Start-Up Company Based on Customer Participation, Innovation, and Bussiness Model. Business Thepry and Practice, 21(1), 115-124. 
Easley, R.W., Madden, C.S. \& Dunn, M.G. (2000). Conducting marketing science: the role of replication in the research process. Journal of Business Research, 48, 83-92.

Epstein, S. (1980). The stability of behavior: II. Implications for psychological research. American Psychologist, 35, 790-806.

Eniyati, Sri., NS, Rina. \& Retnowati. (2018). Penggunaan Fis Mamdani dalam Menentukan Dimensi Kepercayaan Warga Dalam Perspektif Keterbukaan Informasi Publik. Prosiding SINTAK 2018. 109-117. ISBN: 978-602-8557-20-7. https://unisbank.ac.id/ojs/index.php/sintak/article/view/6520?PageSpeed=noscript.

Firdayanti, R. (2012). Persepsi Risiko Melakukan E-Commerce dengan Kepercayaan Konsumen dalam Membeli Produk Fashion Online. Journal of Social and Industrial Psychology, 1(1), $1-7$.

Firmansyah, M., Amelia, R., Jamil, R., Faturochman, F., \& Minza, W. (2019). Benevolence, Competency, and Integrity: Which Is More Influential On Trust In Friendships? Jurnal Psikologi, 18(1), 91-105.

Haekal, Azwar., Widjajanata, Bambang. (2016). Pengaruh Kepercayaan dan Persepsi Resiko Terhadap Minat Membeli Secara Online Pada Pengunjung Website Classifieds di Indonesia. Journal of Business Management and Entrepreneurship Education, 1(1), 181193.

Hubbard, R., Vetter, D., \& Little, E. (1998). Replication in Strategic Management: Scientific Testing for Validity, Generalizability, and Usefulness. Strategic Management Journal, 19(3), 243-254. Retrieved July 16, 2020, from www.jstor.org/stable/3094098

Huberts. (2018). Integrity: What it is and Why it is Important Jurnal Public Integrity 20. Sup1,S18-S32, DOI: 10.1080/10999922.2018.1477404.

Ismunandar, M. (2018). The Effect of Trust Dimension to E-Commerce Costumers Participation (Case Study to E-Commerce Costumers in Bima City. Jurnal Terapan Manajemen dan Bisnis, 4(2), 138-144.

Kharisma, G. (2019). Meninjau Peta E-commerce Indonesia di Awal 2019, Siapa Jadi Juara?

https://id.techinasia.com/peta-ecommerce-indonesia-q1-2019

Koirala, Binod., Araghi, Yashar., Kroesen, Maarten., Ghorbani,Amineh., Hakvoort,Rudi., Herder,Pauline. (2018). Trust, awareness, and independence: Insights from a sociopsychological factor analysis of citizen knowledge and participation in community energy systems. Energy Research \& Social SCience 38 (33-40). https://doi.org/10.1016/j.erss.2018.01.009

Laksmidewi, Dwinita. (2014). Partisipasi Pelanggan, Anteseden dan Pengaruhnya Terhadap Kualitas Jasa: Perspektif Service-Dominant Logic. Jurnal Manajemen, 11(2), 22-37.

Listyorini, S. (2105). Kepercayaan Konsumer terhadap Niat Beli Produk Fashion yang dipasarkan Melalui Media Sosial facobbok (Studi pad mahasiswa S1 Fisip Undip Semarang), Jurnal Imu Sosial, 14(1), 15-27.

Mulyani, E., Saleh, A. \& Yunianto, H. (2015). Hubungan Dimensi Kepercayaan dengan Partisipasi Pemustaka melalui Facebook Fan Page (Studi Library 2.0 di Perpustakaan Nasional RI. Jurnal Pustakawan Indonesia, 14(1), 23-32.

Mustak, M., Aino, E. \& Kaartemo, H. (2016). Customer participation management Developing a comprehensive framework and a research agenda. Journal of Service Management, 27(3), 250 - 275. http://dx.doi.org/10.1108/JOSM-01-2015-0014

Purwanto, FX. (2017). Pengaruh Dimensi Kepercayaan (Trust) terhadap Kepercayaan dalam Membeli Barang Secara Online (Studi Kasus Toko Online Bukalapak.com). Jurnal Saintek, $14(1)$,

$1-49$. https://ldikti7.ristekdikti.go.id/uploadjurnal/SAINTEK\%20Vol\%2014\%20No\%201\%20Ju ni\%202017_SIAP\%20CETAK.pdf 
Ribadu,M. \& Rahman, N. (2019). An Integrated Approach Towards Shariah Compliance ECommerce Trust. Applied Computing and Informatics 15 (1-6). https://www.sciencedirect.com/science/article/pii/S2210832717302375

Ridwan, M. (2019). Pengaruh Faktor Psikologis dan Faktor Kepribadian Terhadap Kepercayaan Pelanggan dan Dampaknya pada Partisipasi Pelanggan E-Commerce di Indonesia. Jurnal $\begin{array}{llll}\text { Media } & \text { Ekonomi } & \text { (JURMEK), } & \text { 24(2), }\end{array}$ http://jurnal.univbinainsan.ac.id/index.php/jurmek/article/view/619/394

Rofiq, A. \& Mula, J., (2010). The Effect of Customers' Trust on E-Commerce: A Survey of Indonesian Customer B to C Transaction. International Conference on Arts, Social Sciences \& Technology. Available at SSRN: https://ssrn.com/abstract=1873952

Sabtu, A.A.S. (2018). Pengaruh Customer Trust, Customer Satisfaction, Ability, dan Benevolence Terhadap Customer Loyalty di Restoran Cepat Saji McDonald's Ambarukmo di Yogyakarta. Jurnal Ekobis Dewantura, 1(9), 85-95.

Sasongko, Enggar., Mustafid., \& Rusgiyono, Agus. (2016). Penerapan Metode Structural Equation Modeling Untuk Analisis Kepuasan Pengguna Sistem Informasi Akademik Terhadap Kualitas Website. Jurnal Gaussian, 5(3), 395-404 .

Sasongko, G. \& Wahyudi, Y. (2019). Dimensi Kepercayaan dalam Usaha Pelepas Uang (Studi Kasus di Kabupaten Semarang). Jurnal Sosial Humaniora (JSH), 12(1), 15-28. http://iptek.its.ac.id/index.php/jsh/article/view/4589

Sekaran, U., \& Bougie, R. (2016). Research Methods for Business: A Skill Building Approach, 7th Edition. Chichester, United Kingdom: Wiley

Setyoparwati, I. (2019). Pengaruh Dimensi Kepercayaan (Trust) Konsumen terhadap Kepuasan Pelanggan pada E-Commerce di Indonesia. Jurnal Ilmiah MEA (Manajemen, Ekonomi, \& Akuntansi), 3(3), 166-176.

Selviana., Setyowati, Retno. (2019). Pengaruh Sikap Belanja Online Terhadap Trust Melalui Mediator Kepuasan Pelanggan. Ikraith-Humaniora, 3(2), 58 - 64.

Star, J.R. (2018). When and Why Replication Studies Should be Published: Guidelines for Mathematics Education Journals. Journal for Research in Mathematics Education, 49(1), 98-103. Retrieved July 16, 2020, from www.jstor.org/stable/10.5951/jresematheduc.49.1.0098

Sudjatmika, F. (2017). Pengaruh Harga, Ulasan Produk dan Keamanan terhadap Keputusan pembelian secara Online di Tokopedia.com. Agora, 5(1), http://publication.petra.ac.id/index.php/manajemen-bisnis/article/view/5227

Surya, W., Astuti, E. \& Susilo, H. (2014). Pengaruh Employee Knowledge, Skill, dan Ability (KSA) Terhadap Penggunaan Sistem Informasi Sumberdaya Manusia dan Kinerja Karyawan. Jurnal Administrasi Bisnis (JAB,) 8(1), 1-7.

Suyanto, Z. \& Sunyoto, A. (2012). Effect the Security, Integrity, and Trust in E-Commerce $\begin{array}{llll}\text { Perfomance. Jurnal Teknologi Informasi, } & 7(20), & \text { 117-122. }\end{array}$ http://jti.respati.ac.id/index.php/jurnaljti/article/download/36/29

Svare, H., Gausdal, A. H., \& Möllering, G. (2019). The function of ability, benevolence, and integrity-based trust in innovation networks. Industry and Innovation, 1-20. https://www.tandfonline.com/doi/full/10.1080/13662716.2019.1632695

Taherdoost, Hamed. (2016). Validity and Reliability of the Research Instrument; How to test the Validation of a Questionnaire/Survey in a Research. International Journal of Academic Research in Management, 5(3), 28-36. DOI: 10.1108/JOSM-01-2015-0014

Tung, L., Tee, C. \& Whye, B. (2001). The Role of Trust in Business-to-Business Electronic Commerce in Singapore. 14th Bled Electronic Commerce Conference. 19-40. https://pdfs.semanticscholar.org/72ac/89dfdec4faf9700673d6706a24a99dd9dde6.pdf 
Ujia, N. \& Munarwoh, R.R. (2016). Pengaruh Kepercayaan Terhadap Minat Beli Online. Jurnal Manajemen dan Akutansi. 19(2), 41-50.

Utami, Sri., Semuel, H. \& Karina, R. (2013). Analisis Pengaruh Trust dan Commitment Terhadap Kepuasan dan loyalitas Pelanggan CV. Sumber Jaya Sakti Tarakan. Jurnal Manajemen Pemasaran, 1(2), 1-9.

Wahyudi, H., Fernando, T., Ahmad, A., Kharani,A., Muhammad, I. \& Milla, M. (2013). Kepercayaan Politik dan Kepuasan Demokrasi Terhadap Partisipasi Politik Mahasiswa. Jurnal Psikologi, 9(2), 95-99. suska.ac.id/index.php/psikologi/article/view/171

Wahyudi, R. (2019). Bank Indonesia: Transaksi E-Commerce per Bulan Capai Rp 13 T.

https://bisnis.tempo.co/read/1274672/bank-indonesia-transaksi-e-commerce-per-bulan-capai-rp13-t

Widowati, H. (2019). Indonesia Jadi Negara dengan Pertumbuhan E-Commerce Tercepat di Dunia. $\quad$ https://databoks.katadata.co.id/datapublish/2019/04/25/indonesia-jadi-negaradengan-pertumbuhan-e-commerce-tercepat-di-dunia

Wong, D. (2017). Pengaruh Ability, Benevolence dan Integrity Terhadap Trust serta Implikasinya terhadap Partisipasi Pelanggan E-Commerce: Studi Kasus pada Pelanggan ECommerce di UBM. Jurnal Riset Manajemen dan Bisnis (JRMB) Fakultas Ekonomi UNIAT, 2(2), 155-168.

Wibowo, Faizal., Djudi, Mochammad., Ruhana, Ika. (2017). Pengaruh Motivasi Kinerja dan Kemampuan Kerja Terhadap Kinerja Pegawai. Jurnal Administrasi Bisnis, 42(1), 172-180.

Windarsyah., H. \& Dirgahayu, T (2010). Analisis Pengaruh Faktor-Faktor Pembangun Trust Terhadap Partisipasi Pengguna Pada C2C E-Commerce Studi Kasus: Forum Jual Beli Kaskus. Teknoin, 16(1), 1-9.

Zhang, Yu., Biao Bingjia. (2018). The Effect of Customer Participation Types on Online Recovery Satisfaction: A Mental Accounting Perspective. Future Internet. 10(97), doi:10.3390/fi10100097. 